\title{
DETERMINANT OF PARTICIPATION IN VISUAL INSPECTION WITH ACETIC ACID (VIA) TEST AMONG PRODUCTIVE AGE WOMEN IN PALEMBANG
}

\author{
Selvi Fitriah, ${ }^{1}$ Nur Fajar Alam, ${ }^{2}$ Haerawati Idris ${ }^{3}$ \\ ${ }^{1}$ Post Graduate of Health Policy \& Administration, Faculty of Public Health, Universitas Sriwijaya \\ ${ }^{2}$ Department of Health Promotion, Faculty of Public Health, Universitas Sriwijaya \\ ${ }^{3}$ Department of Health Policy \& Administration, Faculty of Public Health, Universitas Sriwijaya
}

\begin{abstract}
Background: World Health Organization (WHO) stated that two of 10.000 women in Indonesia have cervical cancer, and an estimation of 26 women die each day because of cervical cancer. The low number of early detection in productive age women lead to an increased number of cervical cancer incidence each year. One strategy of cervical cancer prevention is early detection through test of visual inspection with Acetic Acid (VIA). This study aimed to analyze the determinant of participation of productive age women in VIA test in Palembang.

Methods: The research method used a cross-sectional design. The total population were 253.087 women aged 30-50 years old who are VIA test targets in Palembang. The sampling technique used proportional accidental sampling in each Sub-district in Palembang consisted of 165 respondents who met the inclusion and exclusion criteria. The data collection is done by home visit and using CPC-28 Questionnaire. The data is analyzed using chi-square and multiple logistic regression.

Results: Results showed that the proportion of productive age women who participated in VIA is only $7.9 \%$. Results obtained by multiple logistic regression analysis found significant relationship between education ( $p$ value $=0.037 ;$ OR $=0.27$ ) and perceived barriers ( $p$-value $=0.015 ;$ OR $=13$ ) against participation in the IVA test in productive women in Palembang. Multivariate analysis showed that the perception of barriers is the dominant factor affecting participation in VIA test in productive age women in Palembang.

Conclusions: We found a significant relationship between education and perceived barriers against participation in VIA test in productive age women in Palembang. Therefore a communication strategy is necessary to overcome perceived barriers by women.
\end{abstract}

Keywords: Health beliefs, cervical cancer, VIA Test

\section{DETERMINAN KEIKUTSERTAAN PEMERIKSAAN INSPEKSI VISUAL DENGAN ASAM ASETAT (IVA) PADA WANITA USIA PRODUKTIF DI KOTA PALEMBANG}

\begin{abstract}
ABSTRAK
Latar belakang: World Health Organization (WHO) menyatakan 2 dari 10.000 wanita di Indonesia menderita kanker serviks dan diperkirakan 26 wanita meninggal setiap harinya karena kanker serviks. Masih rendahnya deteksi dini yang dilakukan oleh wanita usia produktif mengakibatkan angka kejadian kanker serviks semakin meningkat setiap tahunnya.Salah satu upaya dalam pencegahan terjadinya kanker serviks adalah dengan melakukan deteksi dini melalui pemeriksaan Inspeksi visual dengan Asam Asetat (IVA). Penelitian ini bertujuan untuk menganalisis determinan keikutsertaan dalam pemeriksaan IVA pada Wanita Usia Produktif di Kota Palembang.

Metode: penelitian menggunakan penelitian kuantitatif dengan desain crossectional. Pengambilan sampel dilakukan secara Proportional accidental sampling di setiap Kecamatan di Kota Palembang sebanyak 165 responden yang memenuhi kriteria inklusi dan eksklusi. Pengumpulan data dilakukan dengan cara home visit mengunakan instrumen kuesioner $C P C-28$ Quetionare. Analisis data menggunakan chi-square dan regresi logistik ganda.

Hasil penelitian: proporsi wanita usia produktif yang ikut serta melakukan pemeriksaan IVA hanya sebesar $7,9 \%$. Berdasarkan hasil analisis regresi logistik ganda diperoleh terdapat hubungan yang bermakna antara pendidikan $(\mathrm{p}$ value $=0,037 ; \mathrm{OR}=0,27)$ dan persepsi hambatan $(\mathrm{p}$ value $=0,015 ; \mathrm{OR}=13)$ terhadap keikutsertaan dalam pemeriksaan IVA pada wanita usia produktif di Kota Palembang.
\end{abstract}

\footnotetext{
${ }^{3}$ Correspondence Address: Haerawati Idris, Faculty of Public Health, Sriwijaya University, Jl. Raya Palembang-Prabumilih km. 32 , Indralaya, Kabupaten Ogan Ilir, Sumatera Selatan email : haera@fkm.unsri.ac.id
} 
Kesimpulan: Hasil analisis multivariat menunjukan bahwa persepsi hambatan merupakan faktor dominan yang mempengaruhi keikutsertaan dalam pemeriksaan IVA pada wanita usia produktif di Kota Palembang. Kata Kunci: persepsi, kanker serviks, pemeriksaan IVA

\section{INTRODUCTION}

Changes in lifestyle, social economy, and globalization are leading to a change in patterns of diseases that caused death, where the numbers of non-infectious diseases increased. One of them which have become a global health problem is cancer. ${ }^{1}$ Cancer is one of the causes of deaths that occurred around the globe. ${ }^{2,3}$

Cervical cancer contributes to $20 \%$ of deaths in developed countries. ${ }^{4}$ The high mortality of cervical cancer caused by the numbers of new cases of cancer was found to be already at an advanced stage condition. ${ }^{5,6}$ This is due to a lack of effective early detection of cervical cancer conducted by women in fertile age. ${ }^{7,8}$ Based on data from the Global Burden Cancer, International Agency for Research on Cancer (IARC) in 2012, cervical cancer ranked second to breast cancer with an incident rate of 17 per 100,000 women, and new cases were found at $13.0 \%$ with $10.3 \%$ the number of deaths per year of all the cancer cases in women in the world. This case shows the high numbers of cancer cases in the world. ${ }^{9}$

Successful control of cancer can be achieved by an effective screening and treatment as early as possible..$^{10,11,12}$ The practical VIA test will contribute to reducing mortality and morbidity rate caused by cervical cancer. ${ }^{13,14}$ It has already been implemented in Indonesia. According to the Ministry of Health Regulation No. 34 the Year 2015, early detection of cervical cancer with VIA test method performed by health care facilities.

The test of early detection of cervical cancer up to 2017 targeted $30 \%$ of the total population of women aged 30-50 years old. The data from the test of early detection of cancer by the Head of the Directorate General of the Ministry of Health indicated that the scope of the national cervical cancer screening from the year 2007 to 2016 was still very low at $5.2 \%$, while South Sumatra ranked third among the provinces with low coverage throughout Indonesia (0.98\%), followed by Gorontalo and Papua. ${ }^{15}$ This problem should be a concern of the South Sumatera government to attempt to improve the coverage of cervical cancer early detection tests.

Palembang, the capital of South Sumatera, has many health facilities, it is easy to access information and health services, but the coverage of VIA test is still relatively low compared to some districts in South Sumatera. Inspection coverage in 2017 amounted to only $14.87 \%$ VIA. There was a decrease in the numbers of women partaking VIA test in November and December 2017. In October 2017 the total of women who took the exam in Palembang VIA were 3,190 women, but on November it decreased to 1,130 women, and on December it kept decreasing to 687 women partaking VIA test. ${ }^{15}$

VIA test is considered to be sensitive by the women because it has an association with their reproductive organs. The women's perception heavily influences their participation in this test. This study aimed to analyze the determinant of participation of productive age women in VIA test.

\section{METHOD}

\section{Design and Sample}

This study was an analytic survey with a cross-sectional method. The population was women aged 30-50 years old who are VIA test targets in Palembang in 2018. They were 253.087 women. The sample was 165 respondents and collected by proportional accidental sampling. The implementation is to divide the population area proportionally to 16 
sub-districts in Palembang, then assigning a portion of the population as a sample by accidental sampling from the 16 sub-districts.

\section{Research Procedure}

Ethical review was carried out in this study with numbers 207/UN9.1.10/KKE/2018. The data collection was done by a home visit through interviews using a questionnaire. Data taken included age, education, occupation, perceived susceptibility, perceived severity, perceived benefits, perceived barriers, cues to action, as independent variable and participation of VIA as dependent variable . Perceived susceptibility is a women's belief about the risk of contracting and getting cervical cancer. Perceived severity is a women's perception of the seriousness of the effects of cervical cancer such as illness, disability, and death. Perceived benefits is a women's belief in the effectiveness of VIA test. Perceived barriers are barriers felt by women to do VIA test. Cues to action are the reason for women to carry out VIA test. The instrument used in this study was CPC-28 Questionnaire. ${ }^{16}$ Each question in the questionnaire perception used Likert Scale.

\section{Data Analysis}

The analysis of data in this study included univariate, bivariate, and multivariate analysis. Univariate analysis was done to describe each independent variables and dependent variable. Bivariate Analysis used Chi-Square test with a confidence level of $95 \%(\alpha=0,05)$. If $p$-value $\leq \alpha$, then there was a significant relationship between independent and dependent variables. Multivariate Analysis used in this study was the multiple logistic regression analysis. ${ }^{17}$

\section{RESEARCH RESULT}

\section{Univariate analysis}

The result of the distribution of independent and dependent variables show in Table 1:

Table 1.

Frequency Distribution of Independent Variables and Dependen variable

\begin{tabular}{|c|c|c|}
\hline \multirow[t]{2}{*}{ Variables } & \multicolumn{2}{|c|}{ Number of Samples } \\
\hline & $\mathbf{n}$ & $\%$ \\
\hline \multicolumn{3}{|l|}{ Participation of VIA } \\
\hline Yes & 13 & 7.9 \\
\hline No & 152 & 92.1 \\
\hline \multicolumn{3}{|l|}{ Age } \\
\hline$\geq 40$ Years & 90 & 54.5 \\
\hline$<40$ Years & 75 & 45.5 \\
\hline \multicolumn{3}{|l|}{ Education } \\
\hline High & 31 & 18.8 \\
\hline Low & 134 & 81.2 \\
\hline \multicolumn{3}{|l|}{ Work } \\
\hline Employee & 45 & 27.3 \\
\hline Unemployed & 120 & 72.7 \\
\hline \multicolumn{3}{|l|}{ Perceived Susceptibility } \\
\hline High & 119 & 72.1 \\
\hline Low & 46 & 27.9 \\
\hline \multicolumn{3}{|l|}{ Perceived Severity } \\
\hline High & 105 & 63.6 \\
\hline Low & 60 & 36.4 \\
\hline
\end{tabular}




\begin{tabular}{lcc} 
High & 138 & 83.6 \\
Low & 27 & 16.4 \\
perception Barriers & & \\
Low & 81 & 49.1 \\
High & 84 & 50.9 \\
Cues To Action & 112 & 67.9 \\
High & 53 & 32.1 \\
Low & & \\
\hline
\end{tabular}

According to the table, the proportion of productive age women who participated of VIA was only $7.9 \%$. The majority of respondents are aged $\geq 40$ years $(54.5 \%)$, less educated $(81.2 \%)$ and unemployed $(72.7 \%)$. The majority of respondents have a high perception of the perceived susceptibility $(72.1 \%)$, the perceived severity $(63.6 \%)$, perceived benefits $(83.6 \%)$, perceived barriers $(50.9 \%)$ and cues to action ( $67.9 \%)$.

\section{Bivariate analysis}

The results of the bivariate analysis show in the table 2 below:

Table 2.

Bivariate Analysis

\begin{tabular}{|c|c|c|c|}
\hline \multirow[t]{3}{*}{ Variables } & \multicolumn{2}{|c|}{ Participation of VIA } & \multirow[b]{2}{*}{ p-value } \\
\hline & Yes & Not & \\
\hline & n (\%) & n (\%) & \\
\hline \multicolumn{4}{|l|}{ Age } \\
\hline$\geq 40$ Years & $10(11.1)$ & $80(88.9)$ & 0.162 \\
\hline$<40$ Years & $3(4)$ & $72(96)$ & \\
\hline \multicolumn{4}{|l|}{ Education } \\
\hline High & $6(19.4)$ & $25(80.6)$ & 0,018 \\
\hline Low & $7(5.2)$ & $127(94.8)$ & \\
\hline \multicolumn{4}{|l|}{ Work } \\
\hline Employee & $5(11.1)$ & $40(88.9)$ & 0.344 \\
\hline Unemployed & $8(6.7)$ & $112(93.3)$ & \\
\hline Perceived Susceptibility & & & 0.114 \\
\hline High & $12(10.1)$ & $107(89.9)$ & \\
\hline Low & $1(2.2)$ & $45(97.8)$ & \\
\hline Perceived Severity & & & 0.136 \\
\hline High & $11(10.5)$ & $94(89.5)$ & \\
\hline Low & $2(3.3)$ & $58(96.7)$ & \\
\hline Perceived Benefits & & & 1,000 \\
\hline High & $11(8)$ & $127(92)$ & \\
\hline Low & $2(7.4)$ & $25(92.6)$ & \\
\hline Perceived Barriers & & & 0,003 \\
\hline Low & $12(14.8)$ & $69(85.2)$ & \\
\hline High & $1(1.2)$ & $83(98.8)$ & \\
\hline Cues to Action & & & 1,000 \\
\hline High & $9(8)$ & $103(92)$ & \\
\hline Low & $4(7.5)$ & $49(92.5)$ & \\
\hline
\end{tabular}

According to the table, two variables were related ( $\mathrm{p}$-value $\leq 0,05)$ with the participation of VIA, they were education and perceived barriers on participation in VIA. 
Table 3.

Logistic Regression Modeling

\begin{tabular}{lcccccc}
\hline Variables & B & SE & Sig & Exp (B) & \multicolumn{2}{c}{ 95\% CI Exp (B) } \\
\cline { 5 - 7 } & & & & & Lower & Upper \\
\hline Perception Barriers & 1,300 & 1,059 & 0,015 & 13.069 & 1,640 & 104.141 \\
Education & 2,570 & 0,624 & 0,037 & 0.272 & .080 & 0.925 \\
Constants & -8.607 & .410 & 0,000 & 8.727 & & \\
\hline
\end{tabular}

According to the table, the most dominant variable affecting the participation of VIA test in productive age women was perceived barriers ( $\mathrm{p}$-value $=0.015$; OR 13). It meant that productive age women who have low perceived barriers would perform VIA test 13 times higher than productive age women who have high perceived barriers.

\section{DISCUSSION}

Age

This results showed that there was no correlation between age and participation in VIA test $(p$-value $=0.162)$. It was different from a theory that one reason women do VIA test is a woman who felt any symptoms or problems in their reproductive organs. Symptoms of cervical cancer alone will generally appear in women aged 40 and above. It is extremely rare in women under or aged 35 years. It is what causes most of the women who perform the test IVA aged 40 and above. $^{18}$

The results of this study were consistent with the research conducted by Pandey and Karmacharya which showed that age was not related to women's behavior in early detection of cervical cancer $(p$ value $=0.698) .{ }^{19}$ According to further analysis, this was because every age group has followed early detection of cervical cancer through VIA test. Older women might be less likely to do further test as recommended by health officials, whereas younger women have the initiatives to keep healthy by taking VIA test.

\section{Education}

This results indicated that there was a significant relationship between education and participation in VIA test. According to the results of the multivariate analysis, education is one of the variables that affect participation in VIA test ( $\mathrm{p}$-value $=0,037 ; 0 \mathrm{R}=0.27$ ).

The results of this study were consistent with the Health Belief Model theory, which stated that the education level of a person would affect knowledge and rational capacity of the health awareness, included the decision to act to prevent cervical cancer through participation in early detection tests. ${ }^{20}$

A study conducted by Pandey and Karmacharya showed that there was a correlation between education and cervical cancer screening behavior with $\mathrm{p}$-value $=$ $0.015(<0.05) .{ }^{19}$ The results of this study were also consistent with research conducted by Nasihah and Lorna. The study showed the correlation between education and the VIA test with p-value $=0.000 .^{21}$ Results of the study found that women with high education tend to participate in VIA test. It caused by someone with high education would be more rational in taking a decision and able to consider and assess what is the benefit of due diligence measures VIA for them and the consequences if they do not do it.

\section{Work}

This results indicated that there was no significant correlation between work and participation in VIA test ( $\mathrm{p}$-value $=0.344)$. It was different from the theory that said women who work generally would be more exposed to information, so they can improve their 
knowledge to do early detection of cervical cancer. $^{22}$

This study also consistent with research done by Martini that showed that there was no relationship between work and early detection of cervical cancer. ${ }^{23}$ Based on further analysis of both working and not working respondents who do not participate in VIA test, working women do not have time to do VIA test, while women who do not work do not take VIA test despite having much free time.

\section{Perceived susceptibility}

This results indicated that there was no correlation between perceived susceptibility and participation in VIA test ( $\mathrm{p}$-value = 0.114). The majority of respondents, both with high perceived susceptibility and low perceived susceptibility, do not participate in VIA test.

It was different with the Health Belief Model theory that said when the perceived susceptibility of a woman is high, they will have to develop health awareness, including involvement in cervical cancer early detection through VIA test. ${ }^{24}$ These results were consistent with the study conducted by Pandey and Karmacharya that said that the perceived susceptibility was not related to the behavior of women in doing early detection of cervical cancer ( $\mathrm{p}$-value 0.245). ${ }^{19}$

Based on the results, respondents' lack of participation in VIA test is because the majority of respondents were not at risk of cervical cancer, especially when they do not show signs and symptoms, or problems in the reproductive organs, then they do not need to take VIA test.

\section{Perceived Severity}

This results indicated that there was no correlation between perceived severity and participation in VIA test ( $\mathrm{p}$-value $=0.136$ ) The majority of respondents, with high perceived severity and low perceived severity, do not participate in VIA test. It was different from the Health Belief Model theory that said that when the perceived severity of productive age women was higher against cervical cancer, they will adopt healthy behaviors including participating in VIA test. ${ }^{24}$

The results were consistent with the research conducted by Pandey and Karmacharya that showed the perceived severity was not related to the behavior of women in the early detection of cervical cancer (p-value 0.245). ${ }^{19}$ Regarding the seriousness or impact of cervical cancer, most women believe that cervical cancer can threaten their relationship with their partner, there is fear to think about cervical cancer. It scares them from taking the test.

\section{Perceived Benefits}

This results indicated that there was no significant correlation between perceived benefits and participation in VIA test ( $p$-value $=1.000)$. The majority of respondents, both with high perceived benefits and low high perceived benefits, do not participate in VIA test. It was different with the Health Belief Model theory that said that when a person is aware or know the benefits of early detection, then she will continue to make these healthy behaviors to prevent of disease, including participation in VIA tests to prevent cervical cancer. $^{24}$

The results were consistent with research conducted by Pandey and Karmacharya that there was no significant correlation between perceived benefits and the behavior of women in the early detection of cervical cancer ( $p$-value 0.075). ${ }^{19}$ Regarding perceived benefit in women, the majority of the respondents have high perceived benefits of VIA test, but still only a few took VIA. Due to ignorance regarding VIA test as well as the fear and shame in taking IVA, so despite knowing the benefits of the test, many women still do not take IVA test. 


\section{Perceived Barriers}

This results indicated that there was a significant correlation between perceived barriers and participation in VIA test. The most significant perceived barriers in this study are the ignorance regarding VIA test. The shame of being inspected and fear of pain during the test also become obstacles for respondents to take VIA test. Based on multivariate analysis, perceived barriers is the dominant factor affecting participation in VIA test.

The results were consistent with the Health Belief Model theory that stated that when the women's perceived barriers are high, and then the healthy behavior will not be formed. ${ }^{24}$ It was also consistent with research conducted by Sawitree Visanuyotin that perceived barriers is the most dominant factor affecting a woman in doing early detection of cervical cancer with OR $=1.97(95 \% \mathrm{CI}=$ 1.24 to 3,10$).{ }^{25}$ Women with high perceived barriers tend to not taking VIA test because of shame and fear of being diagnosed with cancer.

\section{Cues To Action}

This results indicated that there was no significant correlation between the cues to action and participation in VIA test ( $\mathrm{p}$-value $=$ 1.000). The majority of respondents, both with long cues to action and low cues to action were the same. They do not participate in VIA test. It was different from the Health Belief Model theory that when the cues to action of productive age women are higher, they are more motivated to create healthy behavior. $^{23}$

The results were consistent with research conducted by Sawitree Visanuyotin that there was no significant correlation between cues to action with participation in early detection of cervical cancer $(\mathrm{p}$-value $=$ 0.074) ${ }^{25}$ Lack of dissemination by health care workers resulted in respondents not knowing about the VIA test so that most respondents do not participate in taking VIA test.

\section{CONCLUSION}

The results showed that the proportion of productive age women who participated in VIA is only $7.9 \%$. There was a significant correlation between education and perceived barriers to participation in VIA test in productive age women in Palembang. Multivariate analysis showed that the perceived barriers are the dominant factor affecting participation in VIA test in productive age women in Palembang. Therefore, productive age women must actively seek information related to cervical cancer and VIA test to minimize their perceived barriers. Besides, it is necessary to improve health promotion such as counseling and dissemination of VIA test as early detection of cervical cancer. 


\section{REFERENCES}

1. Susanti, A. 'Faktor-Faktor yang Berhubungan Dengan Rendahnya Kunjungan Inspeksi Visual Asam Asetat (IVA) di Wilayah Kerja Puskesmas Halmahera Kecamatan Semarang Timur Tahun 2010.' Jurnal universitas Negeri Semarang, 2010.

2. Rasjidi, I. 'Epidemiologi Kanker Serviks.'Indonesian Journal of Cancer, 2009: Vol. III, No. 3103 - 108.

3. Hidayat, H dan Fitriyat78i Y. 'Hubungan Kejadian Kanker Serviks Dengan Jumlah Paritas Di Rsud Dr. Moewardi Tahun 2013.'JKKI, 2014: Vol.6, No.3 128 - 136.

4. Sabrida, H. 'Peranan Deteksi Dini Kanker untuk Menurunkan Penyakit Kanker 'Stadium Lanjut.' Situasi Penyakit Kanker, semester 1 2015: 16-24.

5. Alfaro, Karla M., et al. 'Factors affecting attendance to cervical cancer screening among women in the Paracentral Region of El Salvador: a nested study within the CAPE HPV screening program.'Alfaro et al. BMC Public Health, 2015: 15: 1058.

6. Orange's, Elkanah Omenge, et al. 'Factors Associated with Uptake of Visual Inspection with Acetic Acid (VIA) for Cervical Cancer Screening in Western Kenya.'PLOS ONE, 2016: DOI:10.1371/journal.pone.0157217.

7. Rahatgaonkar, V. 'VIA in cervical cancer screening.'IOSR Journal of Dental and Medical Sciences (IOSRJDMS), 2012: ISSN: 2279-0861 Volume 1, Issue 1, PP 01-04.

8. Idawu, Ajibola, Samuel Anu Olowookere, Aderonke Tolulope Fagbemi, dan Olumuyiwa Ayotunde Ogunlaja. 'Determinants of Cervical Cancer Screening Uptake among Women in Ilorin, North Central Nigeria: A Community-Based Study.'Journal of Cancer Epidemiology, 2016.Vol.16, No.1

9. Kementerian Kesehatan RI. Buku Panduan Program Nasional Gerakan Pencegahan Dan Deteksi Dini Kanker Leher Rahim Dan Kanker Payudara. 2015.

10. Ma, Grace X, et al. 'Health Beliefs Associated with Cervical Cancer Screening Among Vietnamese
Americans.'Journal of Women's Health, 2013: 22(3): 276-288.

11. Shaheen, Rajyashri Sharma, dan Rashi. 'Visual Inspection with Acetic Acid (VIA) in cervical cancer screening in low resource settings.'Bangladesh Journal of Medical Science, 2014: Vol. 13 No. 04. Page: 454-459.

12. Shobeiri, Fatemeh, Masoumeh Taravati Javad, Parisa Parsa, dan Ghodratollah Roshanaei. 'Effects of Group Training Based on the Health Belief Model on Knowledge and Behavior Regarding the Pap Smear Test in Iranian Women: a Quasi-Experimental Study.' Asian Pacific Journal of Cancer Prevention, 2016: 2871-2876.

13. Nardi, Christina, Prabjot Sandhu, dan Nancy Selix. 'Cervical Cancer Screening Among Minorities in the United States.'The Journal for Nurse Practitioners - JNP, 2016: Volume 12, Issue 10, November/December 2016.

14. Syatriani, Sri. 'Faktor Risiko Kanker Serviks di Rumah Sakit Umum Pemerintah Dr. Wahidin Sudirohusodo Makassar, Sulawesi Selatan.'Jurnal Kesehatan Masyarakat Nasional Vol. 5, No. 6, 2011: Vol. 5, No. 6283 - 288.

15. Dinas Kesehatan Provinsi Sumatera Selatan. ProfilDinas Kesehatan Provinsi Sumatera Selatan. 2017.

16. Urrutia, María Teresa. 'Development And Testing Of A Questionnaire: Beliefs About Cervical Cancer And Pap Test In Chilean Women.'Open Access Electronic Theses and Dissertations, 2009: 309.

17. Sugiyono. Metode Penelitian Kuantitatif, Kualitatif dan R\&D. Bandung: Alfabeta, 2014.

18. Savitri, Astrid, dan dkk. Kupas Tuntas Kanker Payudara, Leher Rahim dan Rahim. Yogyakarta: Pustaka Baru Press, 2015.

19. Pandey, Radha Acharya, dan Era Karmacharya. 'Cervical cancer screening behavior and associated factors among women of Ugrachandi Nala, Kavre, Nepal.'European Journal of Medical Research, 2017: 22-32. 
20. Achmad, Nurjannah. 'Perubahan Pengetahuan Sikap Wanita Usia Subur Sebelum dan Sesudah Diberikan Penyuluhan Tentang Deteksi Kanker Serviks dengan Pemeriksaan Metode IVA di Wilayah Kerja Puskesmas Pembangunan Kecamatan Tarogong Kidul Kota Garut Tahun 2016.'Jurnal Universitas Muhammadiyah Jakarta, 2016.

21. Nasihah, Mimatun, dan Sifia Lorna B. 'Hubungan antara Pengetahuan dan Pendidikan dengan Pelaksanaan Deteksi Dini Kanker Servik Melalui IVA.'Jurnal Midpro, 2013: 20 -26.

22. Bayu, Hinsermu, Yibrah Berhe, Amlaku Mulat, dan Amare Alemu. 'Cervical Cancer Screening Service Uptake and Associated Factors among Age Eligible Women in Mekelle Zone, Northern Ethiopia 2015: A Community Based Study Using Health Belief Model.'PLoS ONE, 2016: Vol.11, No. 3.

23. Martini, Ni Ketut. Hubungan Karakteristik, Pengetahuan dan Sikap Wanita Pasangan Usia Subur dengan Tindakan Pemeriksaan Pap Smear Di Puskesmas Sukawati II. Universitas Udayana Denpasar: Thesis, 2013.

24. Subaris, Heru. Promosi Kesehatan, Pemberdayaan Masyarakat, dan Modal Sosial. Yogyakarta: Nuha Medika, 2016.

25. Visanuyothin, Sawitree, Jiraporn Chompikul, dan Aroonsri Mongkolchati. 'Determinants of cervical cancer screening adherence in urban areas of Nakhon Ratchasima Province, Thailand.'Journal of Infection and Public Health, 2015: 543-552 